\title{
MODEL OF THE COHESION MEASUREMENT OF THE ORGANISATION'S PERSONNEL STRATEGY
}

\author{
Janusz Kroik ${ }^{\mathrm{a}}$, Adam Świda \\ ${ }^{\mathrm{a}, \mathrm{b}}$ Wroclaw University of Science and Technology, Department of \\ Computer Science and Management, Wroclaw, Poland \\ ae-mail: janusz.kroik@pwr.edu.pl \\ be-mail: adam.swida@pwr.edu.pl
}

\begin{abstract}
Purpose: Basic purpose of the article is identifying the cardinal elements of organisational strategy cohesion. Empirical challenge was to create an universal strategic tool for measuring the personnel strategy cohesion in a context of actions other functional strategies.
\end{abstract}

Methodology/approach: For establish theoretical backgrounds authors analysed selected literature of strategic management. Pilot case studies were conducted in a large company from a restaurant industry. The study confirmed the usability of such approach.

Findings: The model tool of studying the personnel strategy cohesion with the operational actions should be addressed to strategic objectives of smaller companies. For larger companies, the proposed model of analysis of the strategy cohesion and operational actions provides opportunities in monitoring the effectiveness of human resource management. Strategic management according to the Kaplan-Norton approach, aids knowledge about the personnel perspective combined with other perspectives of the strategy.

Implications: The presented analyses concerning the analysis of cohesion at the level of the organisation general strategy. Personnel strategy should be considered in the context of the organisation's size and the beliefs of managers concerning the usability of the Kaplan-Norton approach. Effective conduct of the tool indicates the practical potential for testing the personnel strategy cohesion as a qualitative measure of the staff development perspective.

Originality of the paper: Empirical researches results confirmed the adopted assumptions associated with the context of cohesion, due to the characteristics of the sample. The paper is an approach for creating a tool for testing strategy cohesion.

Keywords: strategy, cohesion, personnel, balanced score card

Paper type: Research paper 
MODEL OF THE COHESION MEASUREMENT

Janusz Kroik Adam Świda 
behaviour and procedures, we should ultimately achieve strategic cohesion (Gadomska-Lila, 2013).

With the initial point being conclusions on the essence and importance of the problem of cohesion, the purpose of the paper is to propose a such-quite universal - tool, which would allow for measuring the personnel strategy cohesion in the context of actions performed in this area by the organisation, while preserving integration with the general strategy (values, mission, vision). All the while, it is assumed that higher level of cohesion yields higher generated value for the organisation.

\section{Integration of the personnel strategy with the general strategy}

The problem of integration of both strategies has been the subject of in-depth academic and expert discussions since the beginning of the period of strategic understanding of HRM, i.e. since the beginning of the 1990s (Gadomska-Lila, 2013). D. Guest (1992) stated that strategic integration refers to the organisation's ability to incorporate the issues of human resources management in its strategic plans. Such an approach ensures that various aspects of HRM are coherent, and line managers are allowed to incorporate the HRM perspective in the decisionmaking process (Kelliher and Perrett, 2001).

The idea of relations between these strategies is expressed in the model of R.S. Szuler (1992), who - starting with the strategic business needs - formulates particular actions within the abovementioned 6 components of HRM (Listwan and Stor, 2008). A similar depiction of the model is presented by E. Stańczyk-Hugiet, who indicates missions, goals and the general strategy of the company as the source of the personnel strategy and personnel planning balance sheet (StańczykHugiet, 2013). Another researcher of the strategy problem, G. Gierszewska, expresses an opinion stating that human resources management, as functional strategy, must be consistent with the company strategy and must include relations between strategy and structure. This means: configuration of the place of specific people on specific positions in the organisation with the organisational culture, acquisition and development of employees" (Gierszewska, 2001)

Compliance of the personnel strategy with the general strategy is ensured through pairing of assumptions concerning the organisation's future with its problems to be solved in the field of human resources. This assurance constitutes the cohesion canon in the personnel strategy. M. Armstrong suggests integration of both strategies by answering questions directed at the personnel strategy through the prism of questions directed at the general strategy. They are presented in Table 1.

Various barriers are frequently encountered during the process of integrating the strategy. Some of them have originate from the company's organisational culture. A. Pocztowski specifies the following types of barriers (Pocztowski, 2006): 
MODEL OF THE

COHESION

MEASUREMENT

Janusz Kroik

Adam Świda

Table 1. Integration of strategic issues with HRM problems

Source: Armstrong, 2010.

\begin{tabular}{ll}
\hline Business strategy & HRM strategy \\
\hline $\begin{array}{l}\text { What type company is it and what is } \\
\text { its mission? }\end{array}$ & What kinds of people are needed to fulfil the mission? \\
\hline $\begin{array}{l}\text { Is the traditional system of values } \\
\text { appropriate? }\end{array}$ & How to introduce the required changes? \\
\hline Where is it heading? & $\begin{array}{l}\text { How will the development plans affect the structure, } \\
\text { systems and requirements towards employees? }\end{array}$ \\
\hline $\begin{array}{l}\text { What are the strengths, weaknesses, } \\
\text { opportunities, hazards? }\end{array}$ & $\begin{array}{l}\text { How much are the weaknesses and strengths related to } \\
\text { employee skills? Which opportunities can favourably } \\
\text { develop their motivation? What creates hazards - the } \\
\text { lack of which skills? What can be done to change this } \\
\text { condition? }\end{array}$ \\
\hline $\begin{array}{l}\text { What are the key problems it is } \\
\text { facing? }\end{array}$ & $\begin{array}{l}\text { How can these issues affect the personnel structure, } \\
\text { systems and requirements set for the employees? }\end{array}$ \\
\hline $\begin{array}{l}\text { What are the determining factors of } \\
\text { fulfilment of the assumed mission? }\end{array}$ & $\begin{array}{l}\text { How much does the company's success depend on the } \\
\text { quality, motivation, commitment, and attitudes of the } \\
\text { staff? }\end{array}$ \\
\hline
\end{tabular}

- large focus on current company management objectives

- lack of appropriate competences of personnel managers,

- underestimating employees as a competitiveness factor

- low involvement of line managers in issues related to HRM,

- problems with measuring the HRM effectiveness,

- large risk of investing in human resources, associated both with the source of costs, but also assets, which do not involve transfer of ownership rights,

- reluctance towards changes, hindering implementation of the personnel strategy.

Integration of both strategies does not take place automatically when its formal provisions, procedures or plans are specified. This is determined by the practical side of specific activities, where the leading role should be played by the HR unit. However, it is also often the object of accusations concerning focusing on administrative aspects, lack of strategic intuition and consistency (Cappeli, 2015). The possession of measurement tools of the degree of strategy integration through subjective assessment of people involved in the organisation may stop the possible trend of permanent uncontrolled testing of solutions. In consequence, it may affect the perception of the personnel strategy as a cohesive management construct. That is a main motive of postulated target for the paper.

Implementation of the organisation's strategy requires proper human resources. These resources can be assessed on the basis of quantitative and qualitative criteria. Organisations and companies that pursue their strategies on the basis of the strategic scorecard of Kaplan and Norton have an easier job. The card's perspective (finance, customers, internal processes, development) enable 
implementation of the strategy while preserving the cohesion of many points of view and interests of all participants of the organisation.

The card's structure enables extensive reflection of the development of personnel resources necessary for the implementation of the general strategy for instance: assessment of intellectual capital in the organisation thanks to the application of the strategic scorecard (Jashapara, 2011). An example of such an approach may be the strategy implementation process of a large technical university with the use of the strategic scorecard of Kaplan and Norton. Table 2 presents selected strategic objectives and measures taking account of the development of personnel resources necessary to achieve particular strategic goals of the university. As shown, the card allows for precisely presenting the development plan of personnel resources of the organisation, necessary for the implementation of complex strategic objectives. This allows for planning of the dynamics and then assessing the degree of implementation of the plan and introducing the necessary adjustments. If the implementation of the personnel strategy in the quantitative aspects does not raise any objections, we can proceed to qualitative analyses of the strategic cohesion.

\begin{tabular}{|c|c|c|c|c|c|c|c|c|c|c|}
\hline \multirow{2}{*}{ 这 } & \multirow[b]{2}{*}{ Name } & \multirow{2}{*}{ Meter } & \multirow{2}{*}{$\begin{array}{l}\text { Unit } \\
\text { of me- } \\
\text { asure- } \\
\text { ment }\end{array}$} & \multirow{2}{*}{$\begin{array}{l}\text { Base } \\
\text { value } \\
2015\end{array}$} & \multicolumn{5}{|c|}{$\begin{array}{l}\text { Values planned for } \\
\text { 2015-2019 }\end{array}$} & \multirow{2}{*}{$\begin{array}{l}\text { Target } \\
\text { Value } \\
(\mathbf{2 0 2 0})\end{array}$} \\
\hline & & & & & $\stackrel{\text { กे }}{2}$ & 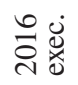 & 홍 & $\stackrel{\infty}{\stackrel{2}{*}}$ & बे & \\
\hline 1 & $\begin{array}{l}\text { INCREASE IN THE } \\
\text { LEVEL OF CORRE- } \\
\text { LATION OF THE } \\
\text { UNIVERSITY'S } \\
\text { OPERATIONS WITH } \\
\text { MARKET NEEDS }\end{array}$ & $\begin{array}{l}\text { Number of } \\
\text { classes held } \\
\text { by practitio- } \\
\text { ners. }\end{array}$ & 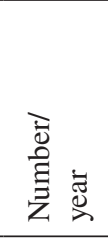 & 5 & 5 & 6 & 6 & 7 & 8 & 10 \\
\hline 2 & $\begin{array}{l}\text { INTERNATIONA- } \\
\text { LISATION OF THE } \\
\text { UNIVERSITY }\end{array}$ & $\begin{array}{l}\text { Number of } \\
\text { foreign lectu- } \\
\text { rers employ- } \\
\text { ed. }\end{array}$ & $\begin{array}{l}\overline{\bar{\Xi}} \\
\text { है } \\
\text { 乙 }\end{array}$ & 6 & 6 & 5 & 8 & 8 & 10 & 12 \\
\hline 3 & $\begin{array}{l}\text { BUILDING THE } \\
\text { PRINCIPLES OF CO- } \\
\text { OPERATION BASED } \\
\text { ON PARTNERSHIP } \\
\text { AND MUTUAL } \\
\text { TRUST }\end{array}$ & $\begin{array}{l}\text { Number of } \\
\text { employees } \\
\text { trained } \\
\text { in raising } \\
\text { interpersonal } \\
\text { competences. }\end{array}$ & 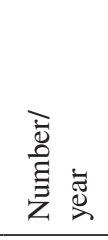 & 15 & 15 & 12 & 15 & 16 & 18 & 20 \\
\hline 4 & $\begin{array}{l}\text { INCREASE IN THE } \\
\text { LEVEL OF ADA- } \\
\text { PTABILITY OF THE } \\
\text { ORGANISATION'S } \\
\text { MODEL AND COM- } \\
\text { PETENCES }\end{array}$ & $\begin{array}{l}\text { Number of } \\
\text { employees } \\
\text { taking part in } \\
\text { various forms } \\
\text { of professio- } \\
\text { nal training. }\end{array}$ & $\begin{array}{l}\overline{\bar{\Xi}} \\
\text { है } \\
\text { 乙 }\end{array}$ & 6 & 6 & 8 & 6 & 8 & 8 & 10 \\
\hline
\end{tabular}

Table 2. Examples of strategic objectives and measures taking account of the development of personnel resources.

Source: prepared by the authors on the basis of the document: System of University Strategic Measurements Base and planned values of achieving strategic targets, Wroclaw University of Science and Technology 2017. 
MODEL OF THE COHESION MEASUREMENT

Janusz Kroik Adam Świda
The obtained image of strategy implementation seen through the quantitative prism may be strengthened/or not by the qualitative measurement of the personnel strategy cohesion. This paper does not determine when such a measurement should be performed. For small enterprises, the qualitative expression of the personnel area may largely replace quantitative measures.

\section{Organisational cohesion as a reflection of strategic cohesion}

When searching - in accordance with the adopted purpose of the paper - for the proper measurement tool, it is important to consider the issue of organisational cohesion. In management sciences, cohesion is sometimes identified with other definitions, among others, integrity, consistency, unity, uniformity, less frequently sensibleness or coherence. When seeking cohesion measures of company business models, T. Falencikowski analysed over ten perspectives with regard to the organisation. Sz. Cyfert sees cohesion as a "gradable feature of the organisation consisting in such conditioning and connecting of all ingredients that a sufficiently strong change in any component may cause the necessity to change the others". P. Leinwand and P.C. Mainari depict coherent companies as organisations with internally distinctive capabilities consistent with their market position (Falencikowski, 2013). In enterprise theories, cohesion is linked to economic results, so both on the grounds of business models and strategy the issue is open. Enterprise cohesion can be located between values for the customer and the skills distinguishing the company, shaped by processes, actions and structures. This results from the understanding of business model cohesion as a "precise and compatible connection - forming a whole - of its components with each other and with the business environment, contributing to the creation of value for customers and the interception of value for the enterprise" (Falencikowski, 2013).

In the perspective of R.P. Rumelt, who identifies two classes of strategies: the good and the bad, coherent strategic actions are considered critical for a good strategy, and the essence of cohesion consists in the particular role of organisational coordination (Rumelt, 2013). Z. Patora-Wysocka explores this problem, noticing the role of analogy, routines and daily activities in the perspective of decision-making cohesion (Patora-Wysocka, 2015). Organisational (internal) cohesion is often neglected as compared to market (external) cohesion. P. Leinwand and P.C. Mainardi claim that most organisations do not pass the coherence test, as their attention is focused mainly on external positioning. They suggest for organisations to first explore what they are really good at and then combine a unique set of skills with market opportunities, without getting ahead of them. In order to be deemed important from the point of view of the company strategy, these skills should be elements that overlap and amplify each other. For this overlapping and amplifying, the market rewards the organisation by an above-average profit. It is defined as the "cohesion bonus" (Leinwand and Mainardi, 2011). The idea of the approach is presented in Table 3. 


\begin{tabular}{ll}
\hline Fields of cohesion & Specific character of cohesion assurance \\
\hline Competition method & $\begin{array}{l}\text { Management staff and employees at each level understand } \\
\text { how to provide benefits for their customers }\end{array}$ \\
\hline Skill system & $\begin{array}{l}\text { Consisting of several skills that direct and propel the imple- } \\
\text { mentation of value proposals }\end{array}$ \\
\hline Adjustment of the product offer & The offer uses the same skill system elements \\
\hline
\end{tabular}

New perspectives of organisational cohesion lead to complex conceptual constructs. One such example is the notion of cohesion in the so-called strategic hybrid proposed by A. Jabłoński. It is a "mix of the business model, strategies and business processes". This cohesion is defined as "mutual and interdependent compliance of all components of the business model, strategies and business processes, with specific criteria that provide the company with the ability to achieve high effectiveness in the long and short run" (Jabłoński, 2015). The author suggests that, in order to be able to achieve favourable results in the long run, it is important to look at the company in a holistic manner as a strategic system determining its development. According to A. Jabłoński, there are two ways of building such a cohesive system - through the strategic triad and/or the strategic hybrid. The first condition occurs when there is compliance in the origin of its attributes (the business model, strategies and business processes) originating from a uniform, primary system. On the other hand, the hybrid condition is present in the case of building a configuration of attributes originating from other, heterogeneous systems adapted to the network environment. At the level of business processes, cohesion leads to the achievement of the synergy effect, which results from the configuration occurring between these processes. It provides integrity, which in turn leads to optimal functionality. Regardless of the raised contexts of organisational cohesion, it depends upon the people who create the proper behaviour practice. This is noticed by the practitioners. J. Kamieński directly notes that the assessment of organisational cohesion has a behavioural origin concerning employees (Kamieński, 2006).

\section{Organisational cohesion as a derivative of knowledge, attitudes and employee invention}

The identified barriers of integration of the personnel strategy with the general strategy, provided by A. Pocztowski, provide a background for the problem of ensuring organisational cohesion. The practitioners see organisational cohesion as a state when the company has:

- a specific vision of the future and organisational objectives, supported by a specific strategy, which takes account of the market reality and its internal situation,
MODEL OF THE COHESION

MEASUREMENT

Janusz Kroik Adam Świda

Table 3. Internal cohesion based on the organisation's skills

Source: prepared by the authors on the basis of Leinwand and Mainardi, 2011. 
MODEL OF THE COHESION MEASUREMENT

Janusz Kroik

Adam Świda

Table 4. Factors distinguished in the study on enterprise cohesion using the OAS method

Source: Guryn, 2012.
- standards, processes and procedures that support the strategy implementation,

- competent employees, willing and able to behave in accordance with standards or to improve them, in order to implement the strategy and achieve the assumed objectives,

- suitable resources, (Kamieński, 2006).

At the same time, when working on organisational coherence, it is recommended to examine detailed aspects of these factors. Only exploration of the problem will allow for deciding whether a given state of organisational cohesion is at a high level or not.

In the personnel perspective, organisational cohesion relates to the following aspects of soft management; effective leadership, organisational culture and climate, approach to employees - namely the motivation system, clear expectations, as well as attitude towards "mutual service" and high quality of work. J. Gornstein, practitioner - specialist in building cohesion of human behaviour, clearly relates organisational cohesion to company strategies and personal communication. Organisational cohesion becomes a challenge for HR departments (Guryn, 2012).

He developed an original OAS (Organizational Alignment Survey) measurement tool, which is also used on the Polish market. The tool uses measurement of correlations between the given organisation's capacity to achieve business results and its basic characteristics. It has eight internal and four external factors, which comprise the organisational cohesion of an enterprise. Some of the eight internal factors are a derivative of actions implemented within the personnel strategy. They are presented in Table 4.

\begin{tabular}{ll}
\hline Internal alignment factors & External alignment factors \\
\hline $\begin{array}{l}\text { Awareness of the mission and the strategy, } \\
\text { Organisational culture, }\end{array}$ & \\
Standards and procedures, & Focus on the market, \\
Quality of internal service, & Monitoring of results, \\
Focus on the quality of work, & Standing out on the market, \\
Climate, & Monitoring of the environment \\
Policy towards employees. & \\
\hline
\end{tabular}

The OAS tool, according to its author, allows for identifying gaps in cohesion. A measuring tool even more focused on the personnel aspects is the proposition of J. Strużyna and M. Majowska. Its idea concerns a comparative list comparing proposals describing particular functional fields (e.g. recruitment, remuneration). They were reduced to the development of 14 opposing pairs of guidelines (e.g. quantity-quality; individual-organisation; top-down - bottom-up focus; effectsbehaviour, etc.), reflecting the scope of activities within HRM (Strużyna and Majowska, 2011). 
They served as a basis for the designed research questionnaire, where the respondent could choose one of three answers related to a specific issue. The tool itself is used for studying the images of alignment of HRM guidelines. It was also tested. K. Gadomska-Lila states that organisational cohesion

MODEL OF THE COHESION MEASUREMENT

Janusz Kroik Adam Świda (defined as organisational alignment) concentrates on three aspects of the actions of management towards the employees. These are; building awareness, communication, education, and development (Gadomska-Lila, 2014). The approach to studying organisational alignment presented therein is reflected in the proposal presented in this paper.

\section{Model of studying the personnel strategy cohesion and its testing}

The issues presented above concerning cohesion (in the organisation) allow for stating that its strategic cohesion, linked to shaping of awareness, attitudes and employee development, is essential. It means translation of the company's strategy implementation into practical operational actions. The point lays in the impact on people, for whom the entire strategy and its sections (perspectives and projects) should be comprehensible and motivational. Therefore, it can be assumed that the issue of the personnel strategy cohesion becomes essential, as it is understood as such a connection and integration of actions and standards of an organisation in HRM that supports implementation of the general strategy and positively affects the satisfaction and commitment of employees. As noted by K. Gadomska-Lila, the cognitive gap existing in this respect is theoretical, empirical and methodical (Gadomska-Lila, 2014). On the other hand, the assurance of cohesion may be disturbed by such situations as: (Szumowski, 2014);

- dispersion of the HR function in the organisational structure,

- insufficient impact of the HR function on the organisation functioning,

- no decisiveness in the HR area,

- no developed tools evaluating the effectiveness of particular HR systems,

- personnel decisions made by main decision-makers without the input of HR specialists,

- decision-makers perceive the role of HR as hardly significant.

It is suggested that the model of the measurement instrument for the formulated personnel strategy cohesion as a quantitative measure for the personnel perspective should contain several components.

Firstly - hypotheses or presumptions that, in the analysis of data from studies, should be at the beginning formulated in such a way so as to emphasise the fact of measuring the cohesion of strategies and operational actions in the personnel sphere, in the context of several strategic assumptions of the company. These assumptions should be related to:

- support for the general strategy implementation through the personnel strategy and operational actions, 
MODEL OF THE COHESION MEASUREMENT

Janusz Kroik Adam Świda
- support for the personnel strategy through human resource management practices,

- support for organisational cohesion, which positively affects the satisfaction and commitment of employees.

Secondly - an ordered set of statements, questions and guidelines, to which the respondents - employees are reacting. For this purpose, the well-known literature proposals concerning the following may be used and developed: type of determinants of strategic cohesion, human resource management practices, and the context of assessment of organisational alignment in the aspects of strategy, organisational culture and human resource management. Finally, proposal of K. Gadomska-Lila was chosen, which contains the following diagnostic fields: 8 for strategy determinants (A), 4 for the practices field (B), and a single-context field for alignment assessments $(\mathrm{C})$. The number of particular items should be adapted to the selected organisation.

Thirdly - selected respondents ensuring the possibility of comparative analysis according to the adopted criteria e.g. job seniority in the organisation, position.

Fourthly - statistical analysis instruments enabling the confirmation of reliability and credibility of relations, hypotheses or assumptions.

The initial (according to the literature patterns) set of statements for the empirical research included more than 60 statements focused around 8 determinants of strategic cohesion, over 20 for human resource management practices, and 4 for the alignment assessment.

The cohesion of the personnel strategy with the operational actions was tested according to the given model. The selected enterprise was the well-known global company - international operator managing restaurant brands, quoted on the stock exchange in Warsaw since 2005. The company's internal materials define the general strategy and its three pillars; People - Brand - Scale. The home office of the company has a separate HR department and has developed standards in personnel areas; selection, assessment, motivation, development. The fact emphasises value of employees for realizing firm's vision and mission. That is why issue of the personal strategy cohesion gives importance for an enterprise. Operational actions are the derivative of many formalised procedures.

Access to the company's employees was accompanied by the confidentiality obligation, and also concerned information about the Company's name (the testing opportunity was provided by Anna Zdunkiewicz, who conducted direct surveys in 2016). The approach to HRM was characterised by professionalism, and thus the subject selected for testing the tool met the framework requirements for testing the personnel strategy cohesion. The information implied that the Company planned to utilise the strategic scorecard. However, an in-depth analysis to the specific nature of operations of the tests subject resulted in adaptation of the initial 
statements and adopted assumptions to the conditions of the enterprise. The set of statements consisted in more than 108 in areas A, B, C, and two rankings of key features (values deemed to be respected by the Company) characterising areas A, B. This is presented in Table 5.

\begin{tabular}{|c|c|c|c|}
\hline Area & $\begin{array}{l}\text { Variable } \\
\text { group } \\
\text { symbol }\end{array}$ & $\begin{array}{l}\text { Variable group } \\
\text { name }\end{array}$ & $\begin{array}{l}\text { Number of statements in the } \\
\text { group (of variables) used for the } \\
\text { selected enterprise }\end{array}$ \\
\hline \multirow{12}{*}{$\begin{array}{l}\text { A. Determinants of } \\
\text { strategic cohesion }\end{array}$} & A1 & Strategy & 6 \\
\hline & $\mathrm{A} 2$ & Strength of culture & 12 \\
\hline & A3 & Team work & 6 \\
\hline & A4 & Focus on results & 6 \\
\hline & A5 & Innovation & 7 \\
\hline & A6 & $\begin{array}{l}\text { Attention to } \\
\text { details }\end{array}$ & 6 \\
\hline & A7 & Learning & 6 \\
\hline & A8 & $\begin{array}{l}\text { Focus on the } \\
\text { customer }\end{array}$ & 6 \\
\hline & A9 & $\begin{array}{l}\text { Readiness for } \\
\text { changes }\end{array}$ & 5 \\
\hline & A10 & Satisfaction & 4 \\
\hline & A11 & Commitment & 4 \\
\hline & & Total & $68+$ ranking of 8 strategy values \\
\hline \multirow{5}{*}{$\begin{array}{l}\text { B. Human reso- } \\
\text { urce management } \\
\text { practices }\end{array}$} & B1 & Selection & 7 \\
\hline & B2 & Assessment & 7 \\
\hline & B3 & Motivating & 11 \\
\hline & B4 & Development & 9 \\
\hline & & Total & $\begin{array}{l}34+\text { ranking of } 11 \text { features in each } \\
\text { group of variables }\end{array}$ \\
\hline $\begin{array}{l}\text { C. Alignment asses- } \\
\text { sment }\end{array}$ & $\mathrm{C} 1$ & Alignment & 6 \\
\hline
\end{tabular}

The authenticity of 1 main presumption (Strategy and operational actions in the personnel sphere support implementation of the general strategy of the enterprise) and 3 auxiliary ones was assessed. Respondents (45 people) consisted in employees at the specialist level, including a group (which gave the study its contextual special character and possibility to make an interesting comparison analyse) of 20 people from the HR area of the enterprise. Act of selecting the two group enables more strategic view for firm's human resource management. Table 6 shows examples of results of the analysis of the Spearman's rank correlation in statements for field A.
MODEL OF THE COHESION MEASUREMENT

Janusz Kroik Adam Świda

Table 5. Outline and structure of factors applied in the study of the personnel strategy cohesion of the chosen company.

Source: General structure (A, B,

C) on the basis of Gadomska-Lila, p. 116-133, proposal of 108 statements and 2 rankings developed for the Company. 
MODEL OF THE

COHESION

MEASUREMENT

Janusz Kroik

Adam Świda

Table 6. Examples of situations with high correlation $r$ between statements expressed according to the Likert scale.

$[\mathrm{Ai} / \mathrm{j}$ - and field no. $, 1 \ldots 8, \mathrm{j}-$ no. of statement in the field]

Source: prepared by the authors.

Table 7. Statements for probes [HRM and others] with crucial statically differences

Source: prepared by the authors.

\begin{tabular}{|c|c|c|c|c|}
\hline No. & Content & No. & Content & $\mathbf{r}$ \\
\hline $\mathrm{A} 1 / 2$ & $\begin{array}{l}\text { The Company has a mission indica- } \\
\text { ting appreciated values and direction } \\
\text { of activities }\end{array}$ & $\mathrm{A} 2 / 1$ & $\begin{array}{l}\text { There is a set of clear and fixed } \\
\text { values, on which the Company's } \\
\text { operations are based }\end{array}$ & 0.78 \\
\hline A. $5 / 2$ & $\begin{array}{l}\text { Employees are encouraged to take } \\
\text { initiative and independently search } \\
\text { for innovative solutions. }\end{array}$ & A5/4 & $\begin{array}{l}\text { Creativity and experimentation are } \\
\text { noticed and rewarded. }\end{array}$ & 0.71 \\
\hline A. $6 / 1$ & $\begin{array}{l}\text { Precision and attention to details are } \\
\text { highly valued traits }\end{array}$ & $\mathrm{A} 6 / 2$ & $\begin{array}{l}\text { Attentive and diligent employees are } \\
\text { highly valued }\end{array}$ & 0.73 \\
\hline
\end{tabular}

Due to the small sample size, the statistical data processing should be viewed with caution (5-point Likert scale for the adopted answers). The basic measurement of sample reliability was performed using the Alfa Cronbach coefficient, which amounted to 0.92 (for three survey fields, respectively: 0.94, $0.89,0.6)$. The research assumptions were verified with the use of the MannWhitney U test and the Spearman's rank correlation. The results confirmed the adopted assumptions associated with the context of cohesion, which, however, due to the characteristics of the sample, does not allow for making clear final conclusions. Nonetheless, its effective conduct indicates the practical potential of such a model for testing the personnel strategy cohesion as a qualitative measure of the staff development perspective. As a part of the research (in which the U test was applied) a two situations of crucial differences among HR team and other employees were noticed.

\begin{tabular}{lllllll}
\hline \multirow{2}{*}{$\begin{array}{l}\text { Num- } \\
\text { ber }\end{array}$} & Statement & \multicolumn{3}{c}{$\begin{array}{l}\text { Arithmetical } \\
\text { Average }\end{array}$} & Test U & \\
\cline { 3 - 7 } A.4/6 & $\begin{array}{l}\text { Employee are motivated for activity and hard } \\
\text { and efficient work }\end{array}$ & 4,0 & 3,5 & $-2,140$ & 0,032 & $\begin{array}{l}\text { Probe } \\
\text { others }\end{array}$ \\
\hline A.8/6 & $\begin{array}{l}\text { Attention for client (internal and external) } \\
\text { and completing clients' needs are appreciated } \\
\text { and awarded }\end{array}$ & 4,25 & 3,75 & $-2,426$ & 0,015 & $\begin{array}{l}\text { HR and } \\
\text { others }\end{array}$ \\
\hline
\end{tabular}

In spite of the remarks - making an effective research points practice capacity that's pattern of examining a personal strategy cohesion. In that approach personal strategy cohesion is an quality measurement of employee development perspective.

\section{Final comments}

The presented analyses concerning the analysis of cohesion at the level of the organisation, the general strategy, and the personnel strategy should be considered in the context of the organisation's size and the beliefs of managers 
concerning the usability of the Kaplan-Norton approach. Small enterprises use simplified rules in the aspect of human resource management. However, it does not exclude the application of this approach. In such a situation, the model of studying the personnel strategy cohesion with the operational actions should be

MODEL OF THE COHESION MEASUREMENT

Janusz Kroik Adam Świda addressed more, through statements, to strategic objectives of smaller companies. Therefore, the suitability of such a tool depends on the adaptable reduction of statements, perhaps while preserving the same three penetration fields A, B, C. For larger companies, the proposed model of analysis of the cohesion of strategies and operational actions provides, on the one hand, subsequent opportunities in monitoring the effectiveness of human resource management. On the other hand, in the situation of strategy management according to the Kaplan-Norton approach, it aids knowledge about the personnel perspective combined with other perspectives of the strategy. It may also be a premise confirming the positive role of the HR unit and a counterbalance to views on the needlessness of the incurred costs and the aversion of employees towards the department (Cappeli, 2015). Pointing by applying that measurement tool (or more upgraded) for assessing personal strategy cohesion generates possibilities for identifying many managerial problems. Authors hope that presented proposition will support strategic value of human resources management.

\section{References}

Armstrong, M. (2010), Strategiczne zarzqdzanie zasobami ludzkimi, Oficyna Wolters Kluwer Business, Warszawa.

Cappeli, P. (2015), „Dlaczego nienawidzimy działu personalnego”, Harvard Business Review Polska, No. 151, pp. 36-45.

Falencikowski, T. (2013), Spójność modeli biznesu. Koncepcja i pomiar, CeDeWu, Warszawa.

Gadomska-Lila, K. (2013), Dopasowanie organizacyjne. Aspekt strategii, kultury organizacyjnej $i$ zarzadzania zasobami ludzkimi, Difin, Warszawa.

Gierszewska, G. (2001), ,Strategia przedsiębiorstwa a zarządzanie zasobami ludzkimi”, in: Ludwiczyński, A., Stopińska, K. (Eds.), Zarzq̨dzanie strategiczne kapitałem ludzkim, Poltext, Warszawa.

Guryn, H. (2012), „Spójność organizacyjna. Rozmowa z Jonem Gornsteinem, prezesem firmy doradczej Persona GLOBAL", Personel i Zarządzanie, No. 8/269, pp. 14-16.

Jabłoński, A. (2015), Spójność hybrydy strategicznej w środowisku sieciowym, Difin, Warszawa.

Jashapara, A. (2011), Knowledge management. An integrated approach, Pearson Education Limited, Harlow England.

Kamieński, J. (2006), „Organizacyjna spójność - najważniejszy nośnik strategii”, available at: www.nf.pl/po-pracy/organizacyjna-spojnosc-najwazniejszy-nosnikstrategii,,7960,295.

Karna, W. (2011), Zmiany w zarządzaniu zasobami ludzkimi w administracji samorządowej, 
MODEL OF THE COHESION MEASUREMENT

Janusz Kroik Adam Świda
Monografie i Studia Instytutu Spraw Publicznych Uniwersytetu Jagiellońskiego w Krakowie, Kraków.

Kelliher, C., Perrett, G. (2011), "Business strategy and approaches to HRM - A case study of new developments in the United Kingdom restaurant industry", Personnel Review, Vol. 30 No. 4, pp. 421-437.

Kroik, J., Świda, A. (2016), „Strategia rozwoju wybranej uczelni: refleksje metodyczne”, in: Barcik, R., Borowiecki, R., Dudek, M., Nowicka-Skowron, M. (Eds.), Zarzadzanie w rozwoju organizacji: wybrane problemy, Wydawnictwo AGH, Kraków, pp. 153-163.

Leinwand, P., Mainardi, C. (2011), „Siła spójności i dyscypliny”, Harvard Business Review Polska, No. 97, pp. 79-85.

Leśniewski , M. (2015), Konkurencyjność miękka przedsiębiorstw, Difin, Warszawa.

Lipka, A. (2000), Strategie personalne firmy, Wydawnictwo Profesjonalnej Szkoły Biznesu, Kraków.

Listwan, T., Stor, M. (2008), Zarzqdzanie kadra menedżerskq w organizacjach międzynarodowych $w$ Polsce, Wydawnictwo Uniwersytetu Ekonomicznego we Wrocławiu, Wrocław.

Patora-Wysocka, Z. (2015), „Spójność decyzyjna i analogia w zarządzaniu zmianą”, Zeszyty Naukowe Politechniki Śląskiej. Seria Organizacja i Zarządzanie, No. 83, Wydawnictwo Politechniki Śląskiej, Gliwice, pp. 539-550.

Pocztowski, A. (2006), „Koncepcje łączenia zarządzania zasobami ludzkimi ze strategią firmy - szanse i bariery", in: Borkowska, S. (Ed.), Zarzadzanie zasobami ludzkimi. Teraźniejszość i przyszłość, Instytut Pracy i Spraw Socjalnych, Warszawa.

Stańczyk-Hugiet, E. (2013), Strategie zarzadzania zasobami ludzkimi z elementami zarządzania wiedza, Poradnik dla pracodawców, część VI Pakietu „Doświadczony pracownik", Wrocław.

Strużyna, J., Majowska, M. (2011), „Metoda badania spójności wytycznych ZZL małych firm", in: Lachiewicz, S., Szymańska, K., Walecka, A. (Eds.), Zarządzanie zasobami ludzkimi w małych i średnich przedsiębiorstwach, Wydawnictwo Politechniki Łódzkiej, Łódź.

Szumowski, W. (2014), „Determinanty realizacji funkcji personalnej. Czynniki wpływające na efektywność oraz bariery rozwoju funkcji”, Marketing i Rynek, No. 5, pp. 12331241.

Szymankowska, A. (2014), „Ewolucja zarządzania zasobami ludzkimi we współczesnej organizacji”, Prace Naukowe Akademii im. Jana Długosza w Czestochowie. Pragmata tes Oikonomias, No. 8, pp. 353-361.

Wroclaw University of Science and Technology (2016), University Development Strategy approved by University Parliament 2016.

Wroclaw University of Science and Technology (2017), System of University Strategic Measurements - Base and planned values of achieving strategic targets, Wroclaw University of Science and Technology 2017. 